\title{
Mortars with phase change materials - Part I: Physical and mechanical characterization
}

\author{
CUNHA Sandra ${ }^{1, a}$, AGUIAR José ${ }^{1, b}$, FERREIRA Victor ${ }^{2, c}$, TADEU António $^{3, \mathrm{~d}}$ \\ and GARBACZ Andrzej, $j^{4, e}$ \\ ${ }^{1}$ University of Minho, Campus de Azurém, 4800-058 Guimarães, Portugal \\ ${ }^{2}$ University of Aveiro, Campus Universitário de Santiago, 3810-193 Aveiro, Portugal \\ ${ }^{3}$ University of Coimbra, Rua Luís Reis Santos - Pólo II da Universidade, 3030-788 Coimbra, \\ Portugal \\ ${ }^{3}$ Warsaw University of Technology, PI. Politechniki 1, 00-661 Warszawa, Poland \\ asandracunha86@gmail.com, ’aguiar@civil.uminho.pt, 'victorf@ua.pt, ${ }^{\mathrm{d}}$ tadeu@dec.uc.pt, \\ ea.garbacz@il.pw.edu.pl
}

Keywords: Phase Change Materials, Mortars, Physical and Mechanical Properties.

\begin{abstract}
In a society with a high growth rate and increased standards of comfort arises the need to minimize the currently high energy consumption by taking advantage of renewable energy sources. The mortars with incorporation of phase change materials (PCM) have the ability to regulate the temperature inside buildings, contributing to the thermal comfort and reduction of the use of heating and cooling equipment, using only the energy supplied by the sun. However, the incorporation of phase change materials in mortars modifies its characteristics. The main purpose of this study was the production and characterization in the fresh and hardened state of mortars with incorporation of different contents of PCM in mortars based in different binders. The binders studied were aerial lime, hydraulic lime, gypsum and cement. For each type of binder, different mortars were developed with different content of PCM. The proportion of PCM studied was $0 \%, 20 \%, 40 \%$ and $60 \%$ of the mass of the sand. It was possible to observe that the incorporation of PCM in mortars caused differences in properties such as workability, microstructure, compressive strength, flexural strength and adhesion.
\end{abstract}

\section{Introduction}

Currently, there is a huge concern about the high energy consumption, verified in the residential sector associated with heating and cooling needs of buildings. Thus, it becomes imperative to implement constructive solutions that increase energy efficiency in buildings. The incorporation of phase change materials (PCM) in mortars appears as a possible solution to minimize this problem, since it allows reducing the frequency of temperatures fluctuations, keeping them closer to the desired temperature range for a longer period. The study of mortars with incorporation of PCM has been a target of study and interest for the scientific community.

Some studies have been published incorporating PCM in construction products. The incorporation of phase change materials in gypsum plasterboard has been the subject of several studies performed, due to its low cost and various possibilities of application [1-4]. Darkwa et al. [3], investigated the behaviour of two solutions with incorporation of PCM in gypsum plasterboard. In one side the plasterboard used had $12 \mathrm{~mm}$ of thickness, all impregnated with PCM in order to compare with another situation in which they applied single plasterboards with $10 \mathrm{~mm}$ of thickness, covered by PCM laminate with $2 \mathrm{~mm}$. The amount of PCM incorporated in both cases was the same. The results showed that the use of PCM laminate is more efficient since it contributed to an increase in the minimum temperature. However, other solutions had also been developed like alveolar PVC panels with PCM macroencapsulated, blocks and bricks [5-6]. Cabeza et al. [5], constructed and monitored the behaviour of concrete test cells, with and without addition of $5 \%$ of 
PCM microcapsules. The incorporation of PCM was made in the concrete used on the roof and south and west walls. During the summer and without ventilation a decrease in maximum temperature and a time lag of about 2 hours were recorded.

The incorporation of PCM in mortars based on aerial lime has already being developed by this research group [7-9]. However, the incorporation of PCM in mortars has been limited to mortars based on aerial lime and gypsum.

The main objective of this work was the development and characterization of mortars with PCM incorporation based in different binders. Twenty seven mortars based on different binders and including different contents of PCM were developed. Their physical and mechanical properties were evaluated, such as workability, microstructure, compressive strength, flexural strength and adhesion.

\section{Phase Change Materials}

Phase change materials possess the capability to alter its own state as function of the environmental temperature [10]. In other words, when the surrounding environmental temperature of PCM increases until the materials fusion point, it suffers a change from a solid state to a liquid state, absorbing and storing the heat energy from the environment. On the other hand when the temperature decreases until the PCM solidification point, the material alters from the liquid state to solid state, releasing the previously stored energy to the environment. This application could be made in coating mortars of buildings, with advantage in the passive regulation of internal temperature with increase of thermal inertia [11].

The PCM must be encapsulated, for its correct use, otherwise during the liquid phase there is a possibility that it moves from the original area of application. There are two main forms of encapsulation, macroencapsulation and microencapsulation. The macroencapsulation is based in the introduction of PCM into tubes, panels or other large containers. It is usually done in containers with more than $1 \mathrm{~cm}$ in diameter and presents a better compatibility with the material, improving the handling in construction [5]. The microencapsulation of phase change material consists on covering the material particles, with a material, usually a polymer, commonly known capsule, with dimensions between $1 \mu \mathrm{m}$ to $60 \mu \mathrm{m}$. The polymer used could be polymethylmethacrylate, polyuria or polyurethane and should respond at some demands of operation, as high heat transfer. The microcapsules can be spherical or asymmetric and with variable shape. The advantage of this encapsulation process is the improvement of heat transfer, through its large surface area $[5,12]$.

In 1983 emerged the first classification of substances used for thermal storage. These are classified as organic, inorganic and eutectic mixtures. Organic materials can be non-paraffinic or paraffinic. Usually, they have congruent phase changes without degradation. The inorganic materials are classified as hydrated salts and metals. The eutectic mixtures result from the combination of two or more compounds of organic and/or inorganic nature. By this way, it is possible to correspond to the need of more suitable transition temperatures for the demands $[5,13]$.

The incorporation of PCM microcapsules in mortars brings social, economic and environmental benefits, demonstrating a significant contribution to a construction with a higher value of sustainability. The social benefits derive from the thermal comfort increase inside buildings, given that nowadays this is an important requirement and frequently demanded by buyers and potential sellers as an important decision parameter. The increase of thermal comfort is achieved by the thermal capacity of the PCM, allowing store and release of energy, keeping the interior temperature sensibly constant, or at least with less variation. The environmental aspect concerns the fossil fuels depletion, given that this technology aims at maintaining constant temperatures inside the building, consequently leading to a decrease on air conditioning equipment usage. The economic benefit is related to the technology adequacy and implementation costs. These should be supported and easily amortized by the user. It may also be noted that the economic benefits of reduced energy consumption and lag times for lower demand, are evident and can be achieved with the use of PCM. 


\section{Materials, compositions and fabrication}

Materials. The selection of the materials took in account previous works [7-9]. In order to understand the influence of adding PCM in mortars were developed mortars for interior coating based on the following binders: aerial lime, hydraulic lime, gypsum and cement. The aerial lime used has a purity of $90 \%$ and density of $2450 \mathrm{~kg} / \mathrm{m}^{3}$. The gypsum used is a traditional one, with high fineness and density of $2740 \mathrm{~kg} / \mathrm{m}^{3}$. The hydraulic lime was a natural lime (NHL5) with density of $2550 \mathrm{~kg} / \mathrm{m}^{3}$. Were also used two types of cement: CEM II B-L 32.5N and CEM I 42.5R with density of $3030 \mathrm{~kg} / \mathrm{m}^{3}$.

The PCM used is composed of a wall in melamine-formaldehyde and a core in paraffin (Fig. 1), with temperature transition of about $22.5^{\circ} \mathrm{C}$ and enthalpy of $147.9 \mathrm{~kJ} / \mathrm{kg}$. These exhibit a transition temperature of $24{ }^{\circ} \mathrm{C}$ in the heating cycle and $21{ }^{\circ} \mathrm{C}$ in the cooling cycle. The dimensions of PCM microcapsules granulometry tests were performed, using a laser particle size analyzer. It was possible to observe a particle size distribution between 5.8 to $339 \mu \mathrm{m}$ and an average particle size of $43.91 \mu \mathrm{m}$ (Fig. 2).

The superplasticizer used was a polyacrylate, with a density of $1050 \mathrm{~kg} / \mathrm{m}^{3}$. The sand used has an average particle size of $439,9 \mu \mathrm{m}$ and a density of $2600 \mathrm{~kg} / \mathrm{m}^{3}$. Finally, the fibers used are synthetic fibers of polyamide, with a length of $6 \mathrm{~mm}$ and a density of $1380 \mathrm{~kg} / \mathrm{m}^{3}$.

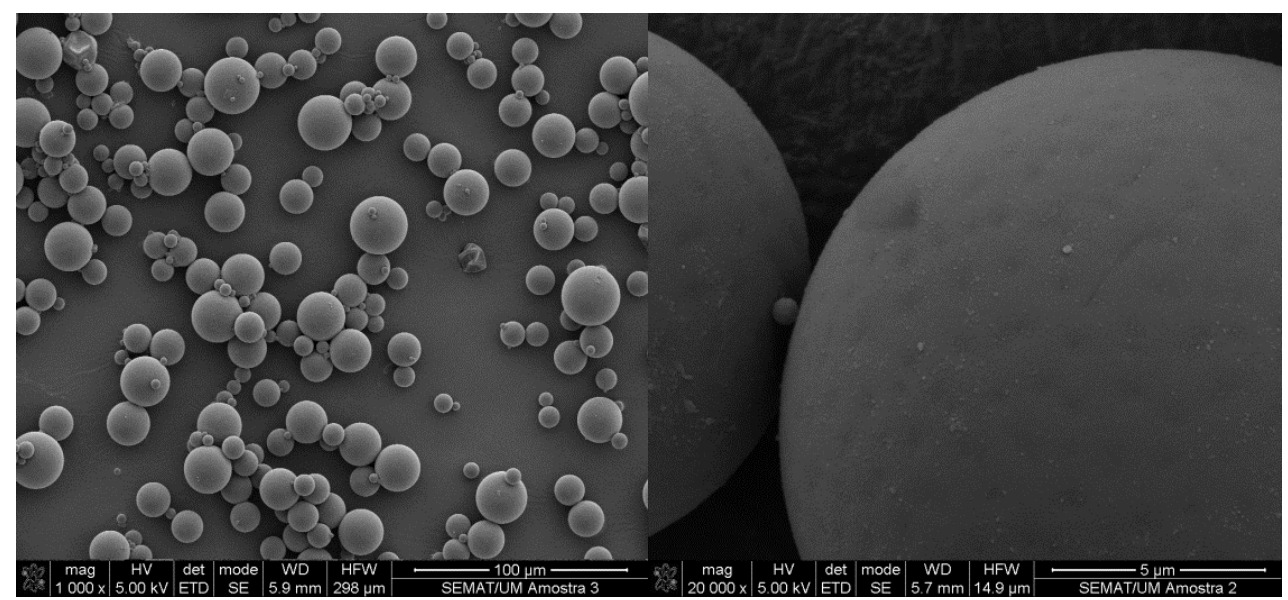

a)

b)

Fig. 1. Microscope observation of polymer surface of the microcapsules: a) Enlargement of 1000x, b) Enlargement of 20000x.

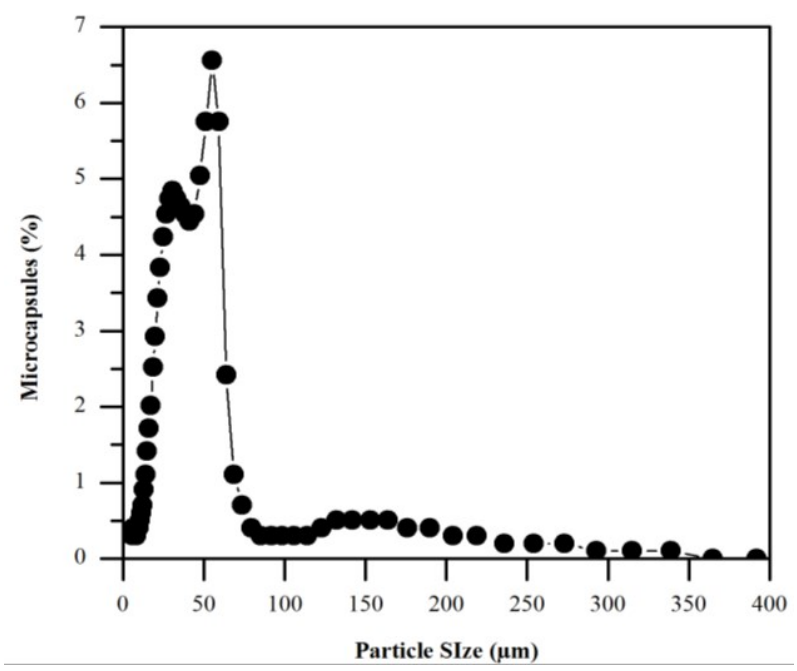

Fig. 2. Particle size of PCM microcapsules. 
Compositions and fabrication. In order to develop this study an experimental campaign was considered, with the main goal of characterizing the produced compositions. Twenty seven compositions were developed taking account the future application of the mortar developed in the construction industry. These compositions were evaluated from the fresh state up to 28 days.

The PCM content was fixed in $0 \%, 20 \%, 40 \%$ and $60 \%$ of mass of aggregate. In order to overcome some of the problems related with the mortar shrinkage and consequent cracking, polyamide fibers and superplasticizer were incorporated.

The mixture procedure and specimens preparation for the compression and flexural tests were performed in accordance with the standard EN 1015-11 [14]. For each composition, 3 prismatic specimens with $40 \times 40 \times 160 \mathrm{~mm}^{3}$ were prepared. Regarding the adhesion tests, the mixture procedure and specimens preparation was performed in accordance to the standard EN 1015-12 [15]. For each studied composition 5 circular test areas with a diameter of $50 \mathrm{~mm}$ were prepared. After their preparation all the specimens were stored during 7 days in polyethylene bags and subsequently placed in the laboratory at regular room temperature (about $22^{\circ} \mathrm{C}$ ) during 21 days. The observation of the microstructure of developed mortars was performed using a scanning electron microscope. For each composition 2 cylindrical specimens with diameter and height of approximately $1 \mathrm{~cm}$ were prepared.

The studied compositions are presented in Table 1. The study used compositions with different contents of PCM and different binders.

Table 1. Mortars formulation $\left(\mathrm{kg} / \mathrm{m}^{3}\right)$.

\begin{tabular}{|c|c|c|c|c|c|c|c|}
\hline Composition & \multicolumn{2}{|c|}{ Binder } & Sand & PCM & SP & Fibers & $\begin{array}{c}\text { Water/ } \\
\text { Binder }\end{array}$ \\
\hline AL500-0PCM & Aerial Lime & 500 & 1447.2 & 0 & 15 & 0 & 0.45 \\
\hline AL500-20PCM & Aerial Lime & 500 & 893.4 & 178.7 & 15 & 0 & 0.47 \\
\hline AL500-40PCM & Aerial Lime & 500 & 597.8 & 239.1 & 15 & 0 & 0.56 \\
\hline AL500-60PCM & Aerial Lime & 500 & 456.3 & 273.8 & 15 & 0 & 0.59 \\
\hline AL600-40PCM & Aerial Lime & 600 & 550.5 & 220.2 & 18 & 0 & 0.46 \\
\hline AL700-40PCM & Aerial Lime & 700 & 485.3 & 194.1 & 21 & 0 & 0.41 \\
\hline AL800-40PCM & Aerial Lime & 800 & 451.2 & 180.5 & 24 & 0 & 0.34 \\
\hline AL800-40PCM-F & Aerial Lime & 800 & 425.2 & 170.1 & 24 & 8 & 0.36 \\
\hline HL500-0PCM & Hydraulic lime & 500 & 1351.1 & 0 & 15 & 0 & 0.54 \\
\hline HL500-20PCM & Hydraulic lime & 500 & 841.1 & 168.2 & 15 & 0 & 0.55 \\
\hline HL500-40PCM & Hydraulic lime & 500 & 571.6 & 228.6 & 15 & 0 & 0.62 \\
\hline HL500-40PCM-F & Hydraulic lime & 500 & 567.2 & 226.9 & 15 & 5 & 0.62 \\
\hline HL500-60PCM & Hydraulic lime & 500 & 431.0 & 258.6 & 15 & 0 & 0.66 \\
\hline C32.5N500-0PCM & CEM II B-L 32.5N & 500 & 1418.8 & 0 & 15 & 0 & 0.55 \\
\hline C32.5N500-20PCM & CEM II B-L 32.5N & 500 & 924.5 & 184.9 & 15 & 0 & 0.51 \\
\hline C32.5N500-40PCM & CEM II B-L 32.5N & 500 & 644.3 & 257.7 & 15 & 0 & 0.56 \\
\hline C32.5N500-40PCM-F & CEM II B-L 32.5N & 500 & 622.2 & 248.8 & 15 & 5 & 0.59 \\
\hline C32.5N500-60PCM & CEM II B-L 32.5N & 500 & 488.3 & 292.9 & 15 & 0 & 0.60 \\
\hline C42.5R500-0PCM & CEM I 42.5R & 500 & 1470.8 & 0 & 15 & 0 & 0.51 \\
\hline C42.5R500-20PCM & CEM I 42.5R & 500 & 924.5 & 184.9 & 15 & 0 & 0.51 \\
\hline C42.5R500-40PCM & CEM I 42.5R & 500 & 632.4 & 252.9 & 15 & 0 & 0.58 \\
\hline C42.5R500-60PCM & CEM I 42.5R & 500 & 483.6 & 290.2 & 15 & 0 & 0.61 \\
\hline G500-0PCM & Gypsum & 500 & 1360.4 & 0 & 15 & 0 & 0.56 \\
\hline G500-20PCM & Gypsum & 500 & 830.6 & 166.1 & 15 & 0 & 0.59 \\
\hline G500-40PCM & Gypsum & 500 & 540.1 & 216.0 & 15 & 0 & 0.70 \\
\hline G500-40PCM-F & Gypsum & 500 & 535.8 & 214.3 & 15 & 5 & 0.70 \\
\hline G500-60PCM & Gypsum & 500 & 396.9 & 238.1 & 15 & 0 & 0.76 \\
\hline
\end{tabular}




\section{Test results and discussion}

Workability. The workability tests were performed with the main goal of verifying the adequacy of application of the developed mortars. The tests were performed based on the flow table method stated by the European standard EN 1015-3 [16]. The resulting value within the test was only considered when between 200-220 mm.

According to Fig. 3 it was possible to verify changes in the amount of water added to the mortars with the incorporation of PCM microcapsules.

It was possible to verify an increase in water/binder ratio with the incorporation of PCM microcapsules. The incorporation of $20 \%$ of PCM microcapsules causes an increase in the amount of water of about 5\%. However, the incorporation of higher contents of PCM leads to a greater increase into water requirement. This can be explained by the reduced particle dimension of the used PCM and by the water absorption of the polymeric wall of the microcapsule.

Thus, it was possible to verify that the gypsum based mortars present higher ratios of water/binder and that the aerial lime based mortars exhibit lower contents of water.

The incorporation of fibers in the mortars with PCM did not cause significant changes in the amount of water added to the mortar, however there was a slight reduction in the flow diameter obtained.

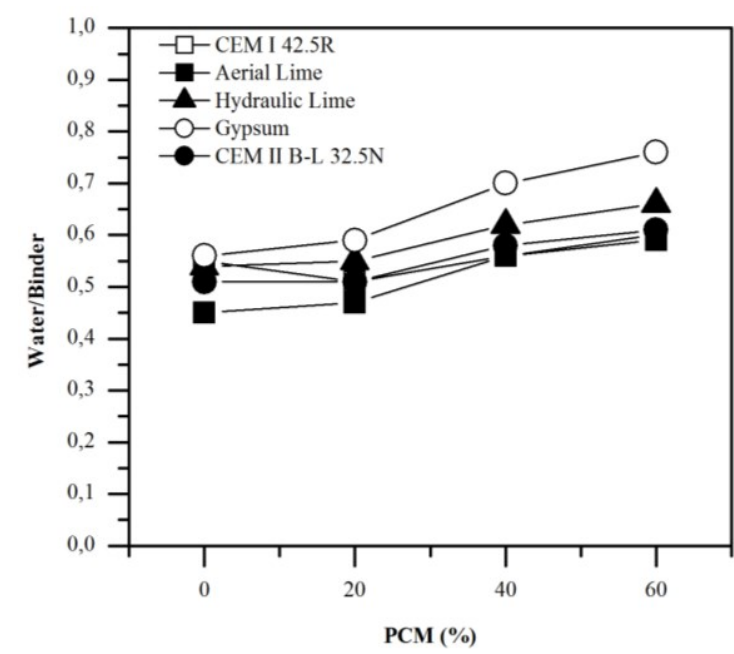

a)

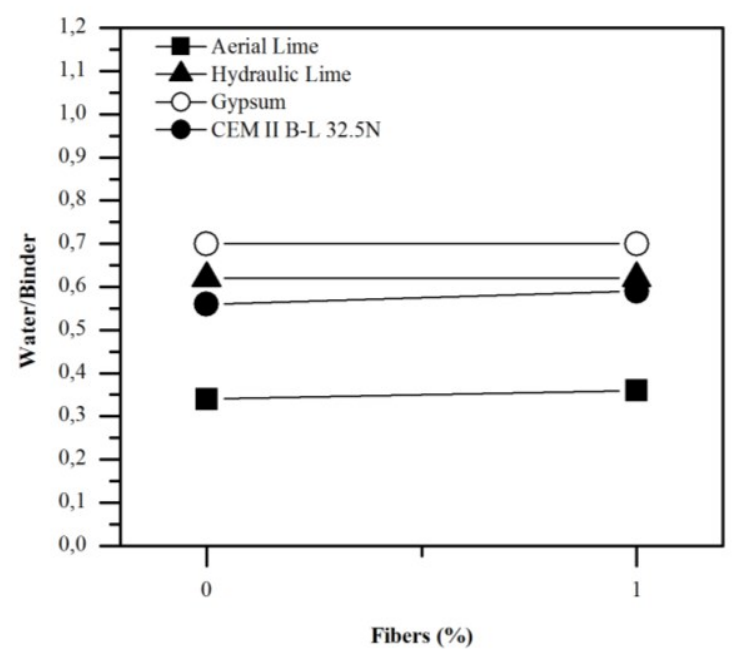

b)

Fig. 3. Workability: a) Variation with PCM content, b) Variation with fibers content.

Flexural and compressive behaviour. The flexural and compressive behaviour was determined based in the standard EN 1015-11. The flexural tests were performed with load control at a speed of $50 \mathrm{~N} / \mathrm{s}$. Compressive tests were realized through the application of a load on the specimen with resource to a metallic piece, rigid enough to make the vertical load uniform. The specimens used for the test were the half parts resulting from the flexural test. The compressive tests were performed with a load control at a speed of $150 \mathrm{~N} / \mathrm{s}$.

According to the results (Fig. 4) it was possible to observe a decrease in mechanical properties caused by the introduction of PCM microcapsules.

Concerning the flexural strength, the incorporation of $20 \%$ of PCM microcapsules resulted in a decrease of flexural superior to $23 \%$, with exception of cement CEM II $32.5 \mathrm{~N}$ B-L based mortars which decrease only about $3 \%$.

Regarding the compressive strength, all tested binders showed also a significant decrease with the incorporation of PCM. The incorporation of $20 \%$ of PCM microcapsules revealed a decrease in the compressive strength at least $37 \%$ when compared to the reference mortar.

The binder which presented lower losses of flexural and compressive strength was the cement CEM II 32.5N B-L. In contrast, the binder which showed higher sensitivity to the incorporation of 
PCM microcapsules and consequently higher losses in the mechanical properties was the aerial lime.
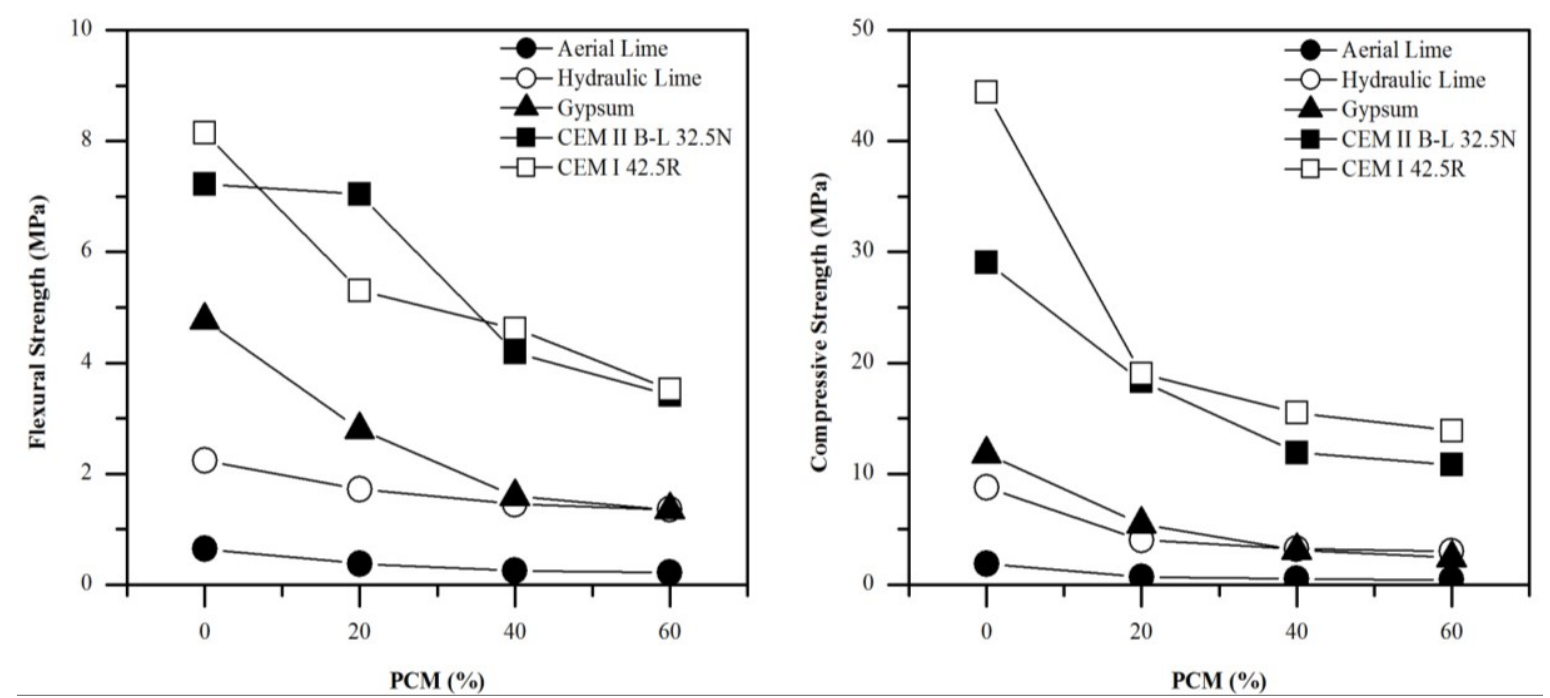

Fig. 4. Flexural and compressive behaviour in mortars with incorporation of PCM.

This behaviour can be justified by the increase of water/binder ratio caused by the introduction of a higher content of PCM which caused higher porosity in mortars.

The incorporation of polyamide fibers in mortars (Fig. 5) led to an increase in the flexural strength of about $51 \%$ for aerial lime based mortars. The mortars based on hydraulic lime, gypsum and cement did not show any influence associated with this addition. The improvement observed essentially for aerial lime based mortars is related to the capacity of fibers to oppose the formation of cracks. This can be due to high quantity of binders into these mortars.

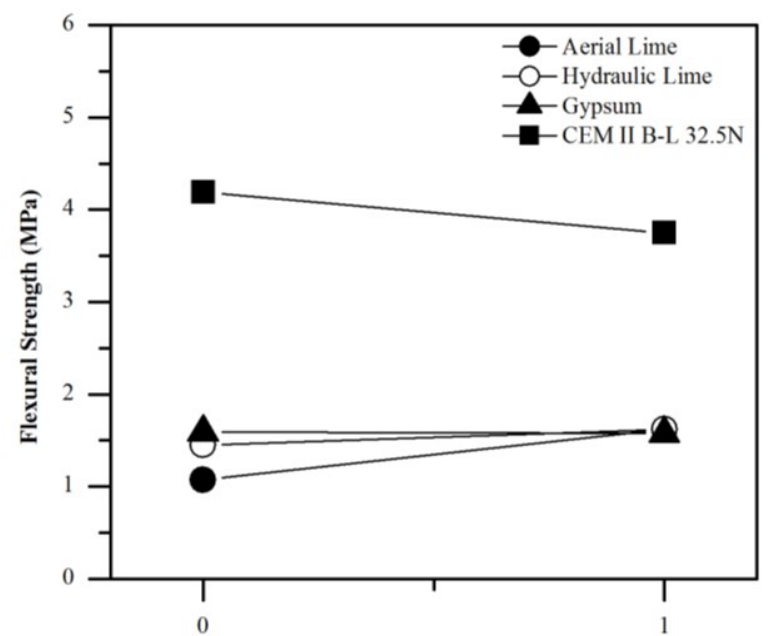

Fibers (\%)

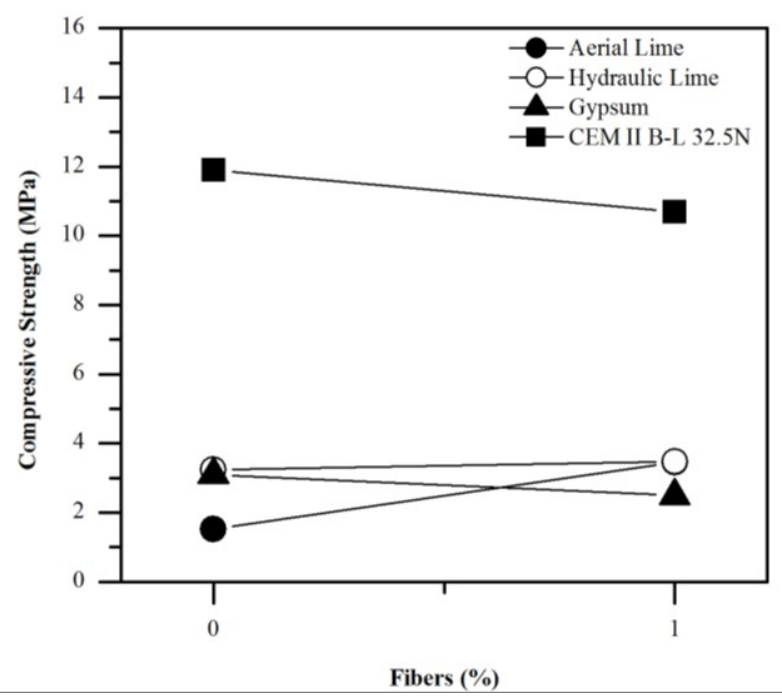

Fig. 5. Flexural and compressive behaviour in PCM mortars with incorporation of fibers.

Concerning the compression strength, it was possible to verify a significant increase in aerial lime based mortars. The remaining binders showed a residual decrease in the compressive strength. In these cases it was possible consider that the incorporation of polyamide fibers was not beneficial.

In order to evaluate the influence of the presence of PCM in the compression strength classification, the mortars were classified according to standard NP EN 998-1 (Table 2) [17]. It was verified that the incorporation of PCM resulted in a lower classification, with the exception of cement based mortars which always correspond to the maximum class (CSIV). Nevertheless this binder still resulted in a decrease in the total compressive strength. 
Microstructure observations. Tests using the electron microscope were performed in order to evaluate the existence of possible incompatibilities between the different materials present in the mortars.

It was possible to observe a good connection between the different materials evidenced by the absence of cracks in the microstructure of the developed mortars.

Fig. 6 shows the microstructure of aerial lime based mortars without PCM and with incorporation of $40 \%$ of PCM. However, these mortars exhibit some cracks caused by high shrinkage (Fig. 7), which can justify the low mechanical strength observed in this type of mortars.

According to Fig. 8 it was possible to verify a good interaction between different materials present in the hydraulic lime based mortars.

Fig. 9 show the microstructure of gypsum based mortars. It was possible to verify a change in the microstructure. However, it was possible to observe a good interaction between different materials.

Fig. 10 and Fig. 11 show the microstructure of cement CEM II B-L 32.5N based mortars and cement CEM I 42.5R based mortars, evidencing again a good interaction between the various constituents of the mortar.

Table 2. Classification of mortars according to standard NP EN 998-1:2010.

\begin{tabular}{|c|c|c|c|}
\hline Composition & Binder & $\begin{array}{l}\text { Compression } \\
\text { Strength [MPa] }\end{array}$ & $\begin{array}{c}\text { Classification NP } \\
\text { EN 998-1:2010 }\end{array}$ \\
\hline CA500-0PCM & Aerial Lime & 1.90 & CS II \\
\hline CA500-20PCM & Aerial Lime & 0.68 & CS I \\
\hline CA500-40PCM & Aerial Lime & 0.51 & CS I \\
\hline CA500-60PCM & Aerial Lime & 0.45 & CS I \\
\hline CA600-40PCM & Aerial Lime & 1.09 & CS I \\
\hline CA700-40PCM & Aerial Lime & 1.18 & CS I \\
\hline CA800-40PCM & Aerial Lime & 1.53 & CS II \\
\hline CA800-40PCM-F & Aerial Lime & 3.46 & CS II \\
\hline CH500-0PCM & Hydraulic lime & 8.76 & CS IV \\
\hline CH500-20PCM & Hydraulic lime & 4.04 & CS III \\
\hline CH500-40PCM & Hydraulic lime & 3.24 & CS II \\
\hline CH500-40PCM-F & Hydraulic lime & 3.48 & CS II \\
\hline CH500-60PCM & Hydraulic lime & 2.99 & CS II \\
\hline C32.5N500-0PCM & CEM II B-L $32.5 \mathrm{~N}$ & 29.05 & CS IV \\
\hline C32.5N500-20PCM & CEM II B-L 32.5N & 18.34 & CS IV \\
\hline C32.5N500-40PCM & CEM II B-L 32.5N & 11.91 & CS IV \\
\hline C32.5N500-40PCM-F & CEM II B-L 32.5N & 10.69 & CS IV \\
\hline C32.5N500-60PCM & CEM II B-L 32.5N & 10.81 & CS IV \\
\hline C42.5R500-0PCM & CEM I 42.5R & 44.40 & CS IV \\
\hline C42.5R500-20PCM & CEM I 42.5R & 19.01 & CS IV \\
\hline C42.5R500-40PCM & CEM I 42.5R & 15.50 & CS IV \\
\hline C42.5R500-60PCM & CEM I 42.5R & 13.90 & CS IV \\
\hline G500-0PCM & Gypsum & 11.78 & CS IV \\
\hline G500-20PCM & Gypsum & 5.48 & CS III \\
\hline G500-40PCM & Gypsum & 3.10 & CS II \\
\hline G500-40PCM-F & Gypsum & 2.49 & CS II \\
\hline G500-60PCM & Gypsum & 2.42 & CS II \\
\hline
\end{tabular}




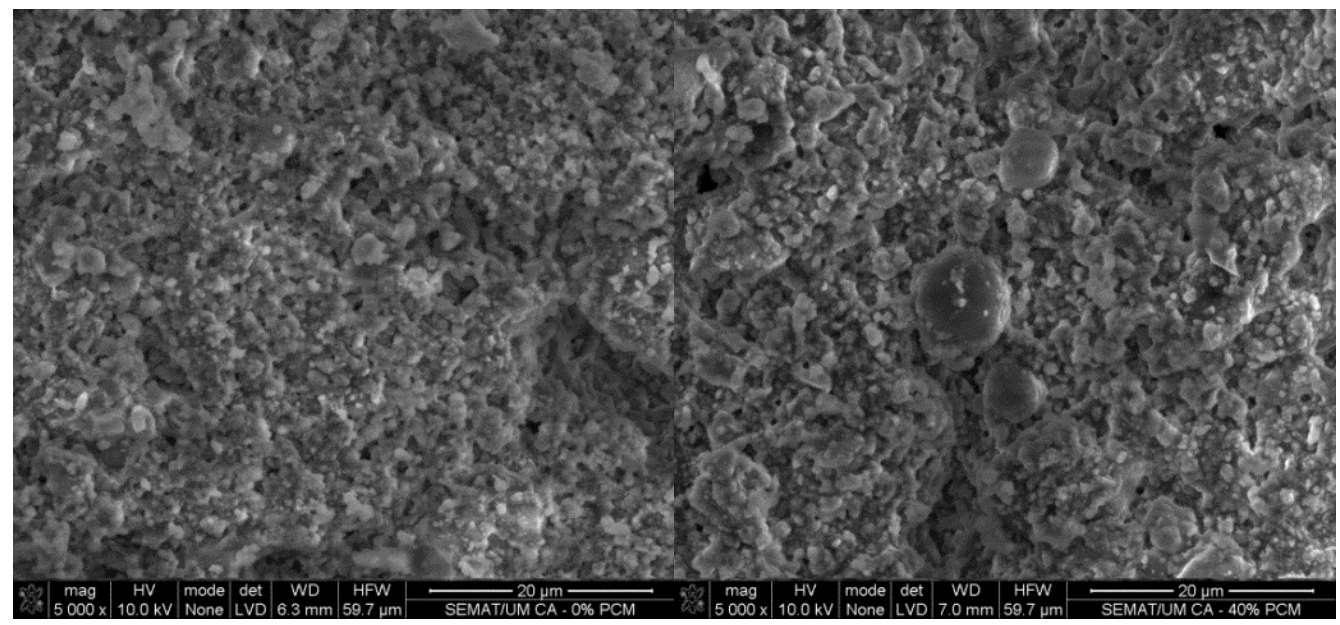

a)

b)

Fig. 6. Microstructure of aerial lime based mortars: a) Mortar without incorporation of PCM microcapsules, b) Mortar with incorporation of $40 \%$ of PCM microcapsules.

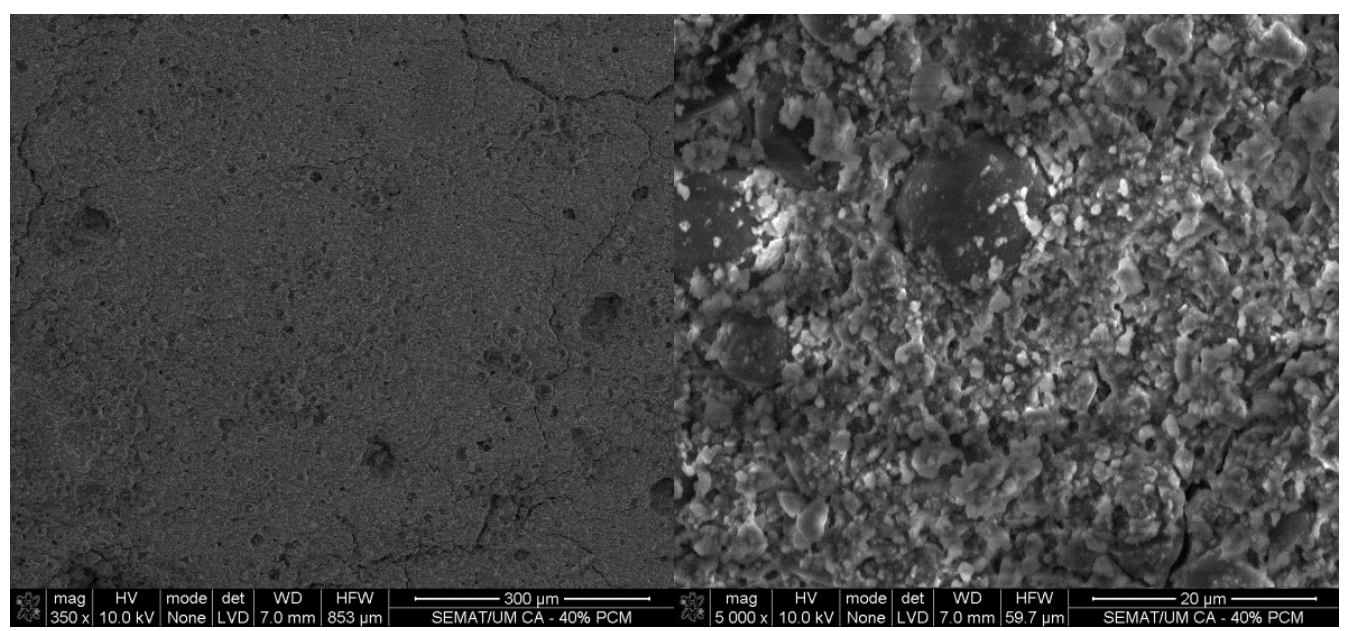

a)

b)

Fig. 7. Cracking caused by shrinkage in the aerial lime based mortars: a) Enlargement of 350x, b) Enlargement of 20000x.

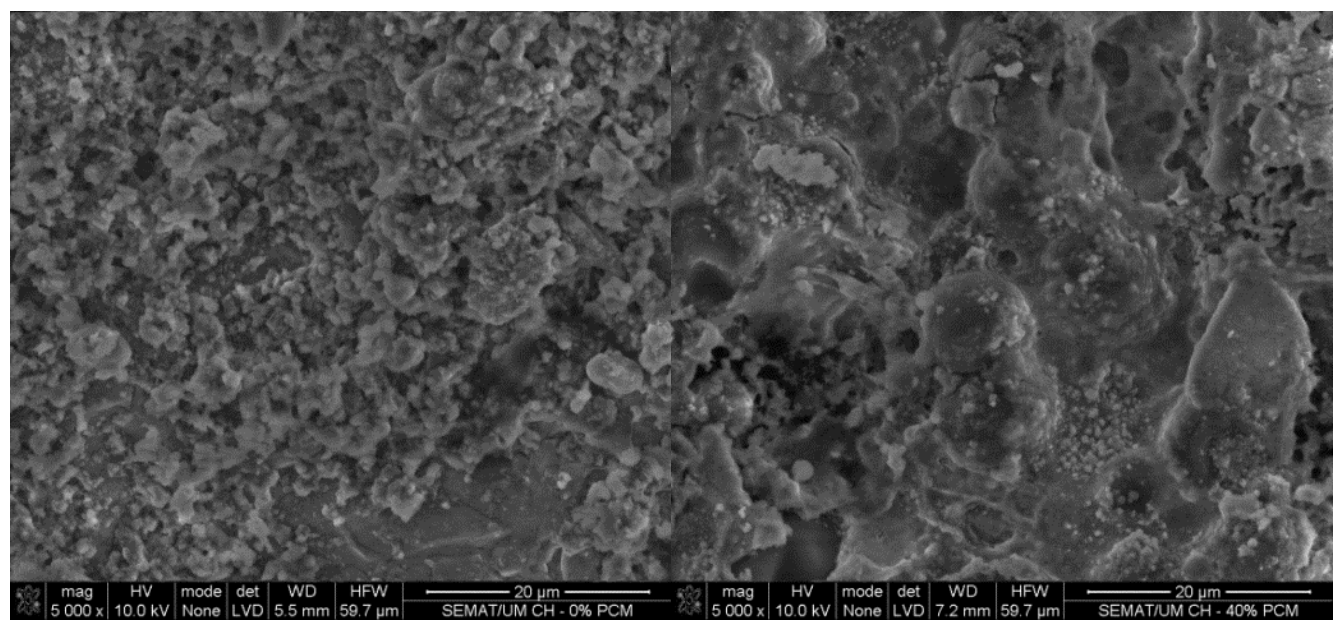

a) b)

Fig. 8. Microstructure of hydraulic lime based mortars: a) Mortar without incorporation of PCM microcapsules, b) Mortar with incorporation of $40 \%$ of PCM microcapsules. 


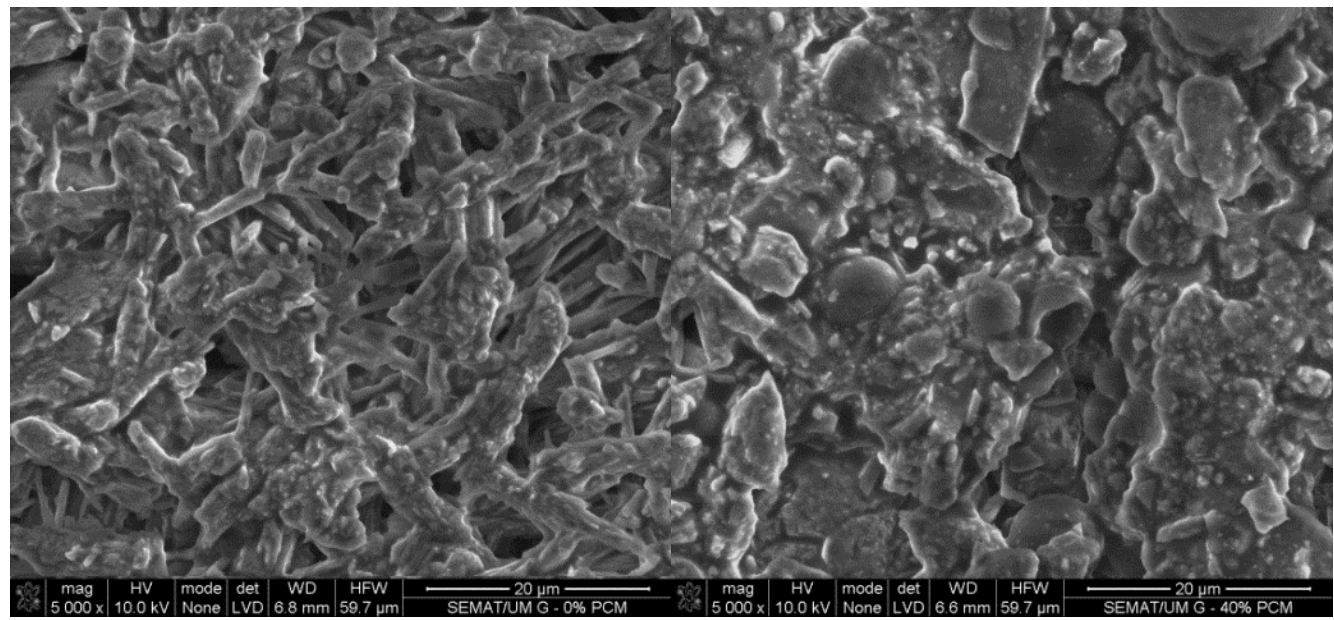

a)

b)

Fig. 9. Microstructure of gypsum based mortars: a) Mortar without incorporation of PCM microcapsules, b) Mortar with incorporation of $40 \%$ of PCM microcapsules.

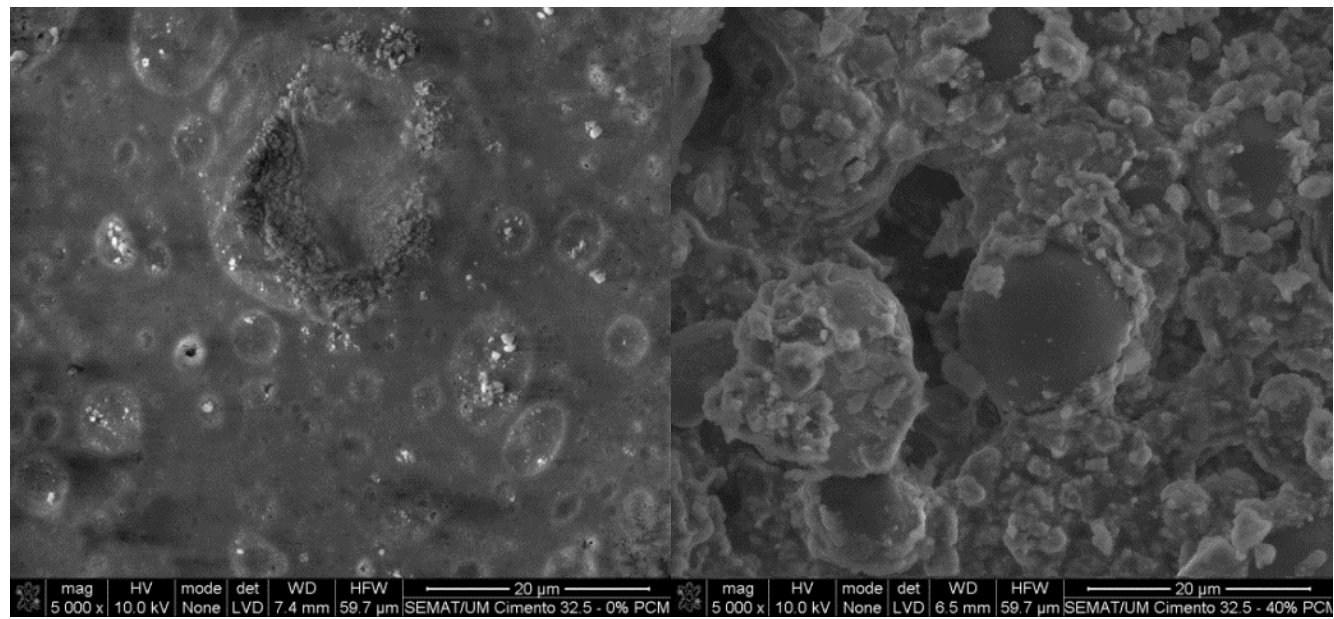

a)

b)

Fig. 10. Microstructure of cement CEM II B-L 32.5N based mortars: a) Mortar without incorporation of PCM microcapsules, b) Mortar with incorporation of $40 \%$ of PCM microcapsules.

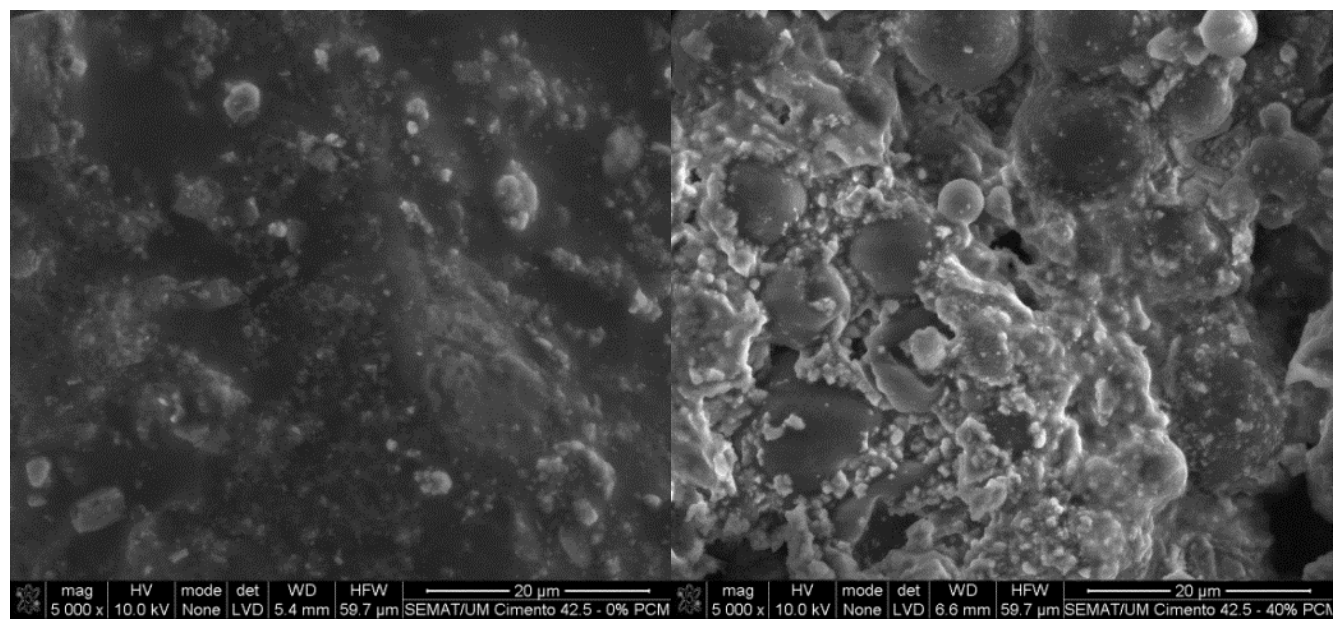

a)

b)

Fig. 11. Microstructure of cement CEM I 42.5R based mortars: a) Mortar without incorporation of PCM microcapsules, b) Mortar with incorporation of $40 \%$ of PCM microcapsules.

Adhesion. The adhesion tests were performed based on the standard EN 1015-12. It was possible to estimate the adhesion of mortar at 28 days, when applied to a ceramic substrate frequently used in 
the construction industry to perform masonry. The tests were performed only for the reference compositions ( $0 \% \mathrm{PCM})$ and those with incorporation of $40 \%$ of PCM and $1 \%$ of polyamide fibers, since the compositions with incorporation of $40 \%$ of PCM and without addition of fibers showed cracks in surface related to shrinkage, making impossible to perform these tests.

According to Fig. 12 and Table 3 it was possible to observe a decrease in adhesion with the incorporation of PCM microcapsules. The incorporation of $40 \%$ PCM leads to a decrease in the value of adhesion of about $33 \%$.

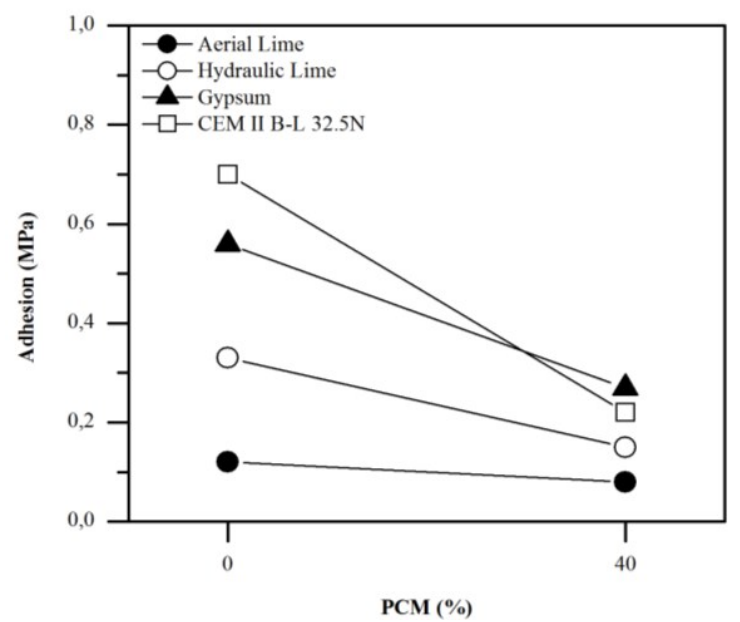

Fig. 12. Adhesion of developed mortars.

Table 3. Adhesion strength of mortars.

\begin{tabular}{|c|c|c|}
\hline Composition & Binder & $\begin{array}{c}\text { Adhesion } \\
{[\mathrm{MPa}]}\end{array}$ \\
\hline CA500-0PCM & Aerial Lime & 0.12 \\
\hline CA800-40PCM-F & Aerial Lime & 0.08 \\
\hline CH500-0PCM & Hydraulic Lime & 0.33 \\
\hline CH500-40PCM-F & Hydraulic Lime & 0.15 \\
\hline C32.5N500-0PCM & CEM II B-L 32.5N & 0.70 \\
\hline C32.5N500-40PCM-F & CEM II B-L 32.5N & 0.22 \\
\hline G500-0PCM & Gypsum & 0.56 \\
\hline G500-40PCM-F & Gypsum & 0.27 \\
\hline
\end{tabular}

\section{Conclusion}

Based on the obtained results, it can be concluded that the incorporation of phase change material in mortars for coating building interiors causes significant changes in their properties in fresh and hardened state. Regarding workability, it was verified that the incorporation of PCM caused an increase in the amount of water added to the mortar in order to give a suitable workability. This increase in the water binder ratio is related to the fineness characteristics of PCM, requiring more water to obtain a homogeneous mortar. On the other hand, the study of mechanical strength (flexural strength, compressive strength and adhesion) showed a decrease with the incorporation of PCM. This phenomenon is a consequence of the presence of a larger amount of water, which leads to a higher porosity in mortars leading to decrease in the mechanical strengths. However, it was possible to obtain mortars classified at least as CSII for all the selected binders.

So, the incorporation of PCM microcapsules in mortars can be seen as a viable solution for applications in the construction industry. Thus, it is possible to conclude that incorporating the PCM mortar can be performed successfully. Mortars with higher performance can be obtained using a higher content of binder, superplasticizer, while the inclusion of fibers can solve problems related to 
high shrinkage. All these procedures can be performed so as to provide an adequate workability to mortars and a similar aspect to the traditional mortars used in the construction industry.

\section{References}

[1] A. Athienitis, C. Liu, D. Hawes, D. Banu, D. Feldman, Investigation of the Thermal Performance of a Passive Solar Test-Room with Wall Latent Heat Storage, Build Environ. 32 (1997) 405-410.

[2] L. Shilei, Z. Neng, F. Guohui, Impact of Phase Change Wall Room on Indoor Thermal Environment in winter, Energy Build. 38 (2006) 18-24.

[3] K. Darkwa, P. O'Callaghan, D. Tetlow, Phase-change drywalls in a passive-solar building, Appl Energy. 83 (2006) 425-435.

[4] P. Schossig, H. Henning, S. Gschwander, T. Haussmann, Micro-encapsulated Phase Change Materials Integrated Into Construction Materials, Sol Energy Mater Sol Cells. 89 (2005) 297-306.

[5] L. Cabeza, A. Castell, C. Barreneche, A. Gracia, A. Fernández, Materials used as PCM in thermal energy storage in buildings: A review, Renew Sustainable Energy Reviews. 15 (2011) 1675-1695.

[6] M. Ahmad, A. Bontemps, H. Sallée, D. Quenard, Thermal Testing and Numerical Simulation of a Prototype Cell Using Light Wallboards Coupling Vacuum Isolation Panels and Phase Change Material, Energy Build. 38 (2006) 673-681.

[7] S. Cunha, V. Alves, J. B. Aguiar, V. M. Ferreira, Use of phase change materials microcapsules in aerial lime and gypsum mortars, Cement Wapno Beton. Special Issue (2012) 17-21.

[8] S. Cunha, J. B. Aguiar, M. Kheradmend, L. Bragança, V. M. Ferreira, Thermal mortars with incorporation of PCM microcapsules, Restoration of Buildings and Monuments. 19 (2013) 171-177.

[9] S. Cunha, J. B. Aguiar, V. M. Ferreira, A. Tadeu, Influence of adding encapsulated phase change materials in aerial lime based mortars, Advanced Materials Research. 687 (2013) 255-261.

[10] Y. Zhang, G. Zhou, K. Lin, K. Zhang, H. Di, Application of latent heat thermal energy storage in buildings: State-of-the-art and outlook, Build Environ. 42 (2007) 2197-2209.

[11]B. Zalba, J. Marín, L. Cabeza, H. Mehling, Review on thermal energy storage with phase change: materials, heat transfer analysis and applications, Appl Therm Eng. 23 (2003) 251-283.

[12] V. Tyagi, S. Kaushik, S.Tyagi, T.Akiyama, Development of phase change materials based microencapsulated technology for buildings: A review, Renew Sustainable Energy Reviews. 15 (2011) 1373-1391.

[13]A. Sharma, V. Tyagi, C. Chen, D. Buddhi, Review on thermal energy storage with phase change materials and applications, Renew Sustainable Energy Reviews. 13 (2009) 318-345.

[14] European Committee for Standardization (CEN). EN 1015-11:1999. Methods of test for mortar for masonry - Part 11: Determination of flexural and compressive strength of hardened mortar (1999).

[15] European Committee for Standardization (CEN). EN 1015-12:2000. Methods of test for mortar for masonry - Part 12: Determination of adhesive strength of hardened rendering and plastering mortars on substrates (2000).

[16] European Committee for Standardization (CEN). EN 1015-3:2004. Methods of test for mortar for masonry - Part 3: Determination of consistence of fresh mortar (by flow table) (2004).

[17] Portuguese Institute for Quality (IPQ). NP EN 998-1:2013. Specification for masonry mortars Part 1: Plastering mortars for interior and exterior (2013) (in Portuguese). 


\section{Sustainable Construction Materials}

10.4028/www.scientific.net/KEM.634

\section{Mortars with Phase Change Materials - Part I: Physical and Mechanical Characterization} 10.4028/www.scientific.net/KEM.634.22

\section{DOI References}

[1] A. Athienitis, C. Liu, D. Hawes, D. Banu, D. Feldman, Investigation of the Thermal Performance of a Passive Solar Test-Room with Wall Latent Heat Storage, Build Environ. 32 (1997) 405-410. http://dx.doi.org/10.1016/S0360-1323(97)00009-7

[2] L. Shilei, Z. Neng, F. Guohui, Impact of Phase Change Wall Room on Indoor Thermal Environment in winter, Energy Build. 38 (2006) 18-24. http://dx.doi.org/10.1016/j.enbuild.2005.02.007

[3] K. Darkwa, P. O'Callaghan, D. Tetlow, Phase-change drywalls in a passive-solar building, Appl Energy. 83 (2006) 425-435. http://dx.doi.org/10.1016/j.apenergy.2005.05.001

[4] P. Schossig, H. Henning, S. Gschwander, T. Haussmann, Micro-encapsulated Phase Change Materials Integrated Into Construction Materials, Sol Energy Mater Sol Cells. 89 (2005) 297-306. http://dx.doi.org/10.1016/j.solmat.2005.01.017

[5] L. Cabeza, A. Castell, C. Barreneche, A. Gracia, A. Fernández, Materials used as PCM in thermal energy storage in buildings: A review, Renew Sustainable Energy Reviews. 15 (2011) 1675-1695.

http://dx.doi.org/10.1016/j.rser.2010.11.018

[6] M. Ahmad, A. Bontemps, H. Sallée, D. Quenard, Thermal Testing and Numerical Simulation of a Prototype Cell Using Light Wallboards Coupling Vacuum Isolation Panels and Phase Change Material, Energy Build. 38 (2006) 673-681.

http://dx.doi.org/10.1016/j.enbuild.2005.11.002

[8] S. Cunha, J. B. Aguiar, M. Kheradmend, L. Bragança, V. M. Ferreira, Thermal mortars with incorporation of PCM microcapsules, Restoration of Buildings and Monuments. 19 (2013) 171-177.

http://dx.doi.org/10.1515/rbm-2013-6592

[9] S. Cunha, J. B. Aguiar, V. M. Ferreira, A. Tadeu, Influence of adding encapsulated phase change materials in aerial lime based mortars, Advanced Materials Research. 687 (2013) 255-261. http://dx.doi.org/10.4028/www.scientific.net/AMR.687.255

[10] Y. Zhang, G. Zhou, K. Lin, K. Zhang, H. Di, Application of latent heat thermal energy storage in buildings: State-of-the-art and outlook, Build Environ. 42 (2007) 2197-2209. http://dx.doi.org/10.1016/j.buildenv.2006.07.023

[12] V. Tyagi, S. Kaushik, S. Tyagi, T. Akiyama, Development of phase change materials based microencapsulated technology for buildings: A review, Renew Sustainable Energy Reviews. 15 (2011) 13731391.

http://dx.doi.org/10.1016/j.rser.2010.10.006

[13] A. Sharma, V. Tyagi, C. Chen, D. Buddhi, Review on thermal energy storage with phase change materials and applications, Renew Sustainable Energy Reviews. 13 (2009) 318-345.

http://dx.doi.org/10.1016/j.rser.2007.10.005 